\title{
Modern Status of Birds of Prey of the Opuksky State Nature Reserve
}

\section{СОВРЕМЕННОЕ СОСТОЯНИЕ ХИЩНЫХ ПТИЦ ПРИРОДНОГО ЗАПОВЕДНИКА «ОПУКСКИЙ»}

\author{
Sikorsky l.A. (Opuksky State Nature Reserve, Feodosia, Republic of Crimea, Russia) \\ Сикорский И.А. (Государственное бюджетное учреждение природный заповедник \\ “Опукский”, Феодосия, Республика Крым, Россия)
}

\section{Контакт}

Игорь Сикорский

ГБУПЗ “Опукский"

298108, Россия

Республика Крым,

Феодосия,

б-р ААмираиьский,

$7 E / 4 H$

opuk2011@mail.ru

\section{Contact:}

Igor Sikorsky

Opuksky State Nature

Reserve

Admiral Boulevard

$7 \mathrm{E} / 4 \mathrm{H}$

Feodosia,

Republic of Crimea,

Russia, 298108

opuk2011@mail.ru

\section{Резюме}

В настояшей работе приводятся сведения о состоянии фауны хишных птиц заповедника "Опукский" за период с 2010 по 2018 гг. По состоянию на 1 декабря 2018 г. на территории заповедника и на смежных с ним территориях зарегистрирован 261 вид птиц (77\% крымской фауны птиц), в том числе Аневные хишные птицы представлены 28 вилами (12\% от общего количества видов птиц заповедника), которые принацежат к 12 родам, из которых лишь 10 (36\%) гнездятся относительно регулярно (вкиючая окрестности заповедника).

Киючевые слова: пернатые хишники, хишные птицы, заповедник "Опукский», Крым.

Поступима в реАакцию 20.08.2018 г. Принята к публикации 10.10.2018 г.

\section{Abstract}

This paper provides information on the status of Birds of Prey in the Opuksky State Nature Reserve from 2010 to 2018. As of December $1^{\text {st }}$ of 2018,261 bird species (77\% of the total Crimean bird fauna) have been registered on the territory of the Reserve and adjacent territories, including 28 species of Birds of Prey (12\% of the total number of bird species in the reserve), which belong to 12 genera. Only 10 species out of 28 (36\%) nest relatively regularly on the studied territory (that includes Reserve and its surrounding areas).

Keywords: birds of prey, raptors, Opuksky Nature Reserve, Crimea.

Received: 20/08/2018. Accepted: 10/10/2018.

DOI: $10.19074 / 1814-8654-2018-37-49-53$

В границах природного заповедника "Опукский" (Аалее - заповедник), плошаць которого - 1592,3 га, находятся: территория горы Опук, солёное озеро Кояшское и прилегаюшая акватория Чёрного моря с островками Скамы-Корабли. Его территория расположена на юге Керченского полуострова (Республика Крым, Россия).

Заповедник преАставляет собой сложную экологическую систему, которая вкиючает биогеоценозы со своими уникаиьными наборами видов фауны хишных птиц. Без целостного, системного анамиза этой экосистемы невозможно решать вопросы оптимамьного управления Аанной территорией и сохранения биологического разнообразия хишных птиц заповедника.

Современное состояние хишных птиц нельзя получить без анализа их тросических связей. Роль хишных птиц определяется, прежле всего, своеобразием их вершинного положения в трофических пирамидах экосистем.

Курганник (Buteo rufinus). Окрестности с. Марьевка, 05.01.2014 г. Фото И. Сикорского.

Long-Legged Buzzard (Buteo rufinus). The neighborhood of Maryevka, 05/01/2014. Photo by I. Sikorsky.
The boundaries of the Opuksky State Nature Reserve (later - the Reserve), covered an area of 1592,3 hectares and includes a mountain Opuk, a salt lake Koyashskoye and an adjacent area of the Black Sea with small rocky islands "Skaly-Korabli". The Reserve locates on the south of the Kerch Peninsula, Crimea.

The Reserve is a complex ecological system that includes biogeocenoses with their unique sets of raptors species. Without a holistic, systematic analysis of this ecosystem, it is impossible to solve the issues of optimal management of this territory and conservation of the biodiversity of Birds of Prey.

The actual state of Birds of Prey cannot be obtained without an analysis of their trophic connections. The role of Birds of Prey is determined primarily by the originality of their top position in the trophic pyramids of ecosystems.

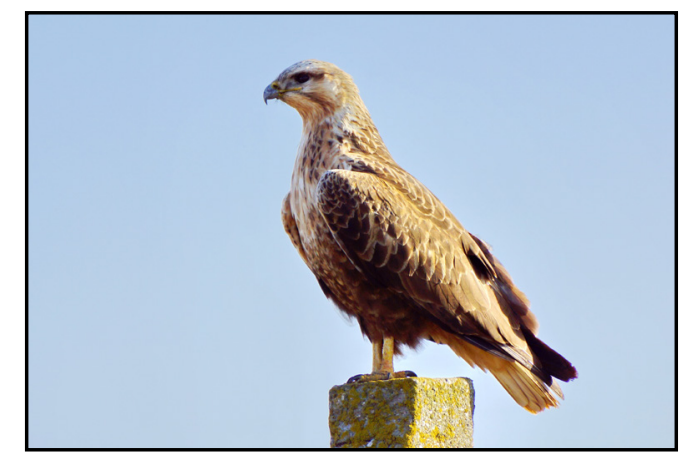


Табл. 1. Статус, регумярность встречаемости и оценка численности видов Аневных хишных птиц природного заповедника “Опукский”.

Table 1. Status, frequency and estimation of population number of Birds of Prey in the Opuksky State Nature Reserve.

\begin{tabular}{|c|c|c|}
\hline № & Вим / Species & $\begin{array}{r}\text { Статус вида, регулярность } \\
\text { пребывания, оценка } \\
\text { численности } \\
\text { Status, frequency and } \\
\text { estimation of population } \\
\text { number }\end{array}$ \\
\hline 1 & Степная пустельга / Lesser Kestrel (Falco naumanni Fleischer, 1818)* & Гн, $М, \ni, 1$ \\
\hline 2 & Пустельra / Common Kestrel (Falco tinnunculus Linnaeus, 1758) & $\Gamma \mathrm{H}, 3, \mathrm{M}, \mathrm{P}, 3$ \\
\hline 3 & Кобчик / Red-Footed Falcon (Falco vespertinus Linnaeus, 1766) & Гн, $М, \ni, 1$ \\
\hline 4 & Аербник / Merlin (Falco columbarius Linnaeus, 1758) & $3, P, 1$ \\
\hline 5 & Чеглок / Hobby (Falco subbuteo Linnaeus, 1758) & Гн, $\mathrm{M}, \ni, 1$ \\
\hline 6 & Балобан / Saker Falcon (Falco cherrug J.E. Gray, 1834)* & Гн, $3, \mathrm{P}, 1$ \\
\hline 7 & Cancan / Peregrine Falcon (Falco peregrinus brookei Tunstall, 1771 Sharpe, 1873)* & Гн, 3, Э, 1 \\
\hline- & Скопа / Osprey (Pandion haliaetus Linnaeus, 1758)* & $M, \ni, 1$ \\
\hline 8 & Ocoe^ / European Honey-Buzzard (Pernis apivorus Linnaeus, 1758) & Гн, $M, P, 1$ \\
\hline 9 & Чёрный коршун / Black Kite (Milvus migrans Boddaert,1783) & $M, H, 2$ \\
\hline 10 & Орлан-белохвост / White-Tailed Eagle (Haliaeetus albicilla Linnaeus, 1758)* & $3, P, 1$ \\
\hline- & Чёрный гриср / Cinereous Vulture (Aegypius monachus Linnaeus, 1766)* & 3a, Э, 1 \\
\hline 11 & Змееям / Short-Toed Eagle (Circaetus gallicus J.F.Gmelin, 1788)* & Гн, 3, P, 1 \\
\hline 12 & Болотный лунь / Marsh Harrier (Circus aeruginosus Linnaeus, 1758) & Гн, 3, P, 2 \\
\hline 13 & Полевой лунь / Hen Harrier (Circus cyaneus Linnaeus, 1766) & $3, M, P, 2$ \\
\hline 14 & Степной мунь / Pallid Harrier (Circus macrourus S.G. Gmelin, 1771)* & $3, \mathrm{M}, \mathrm{H}, 1$ \\
\hline 15 & Ауговой мунь / Montagu's Harrier (Circus pygargus Linnaeus, 1758)* & $\mathrm{M}, \mathrm{H}, 1$ \\
\hline 16 & Перепелятник / Sparrowhawk (Accipiter nisus Linnaeus, 1758) & $3, M, P, 1$ \\
\hline 17 & Тетеревятник / Goshawk (Accipiter gentilis Linnaeus, 1758) & $3, \ni, 1$ \\
\hline 18 & Канюк / Common Buzzard (Buteo buteo вки. buteo + vulpinus) Linnaeus, 1758) & Гн, 3, M, Р, 1 \\
\hline 19 & Курганник / Long-Legged Buzzard (Buteo rufinus Cretzschmar, 1829)* & Гн, 3, P, 1 \\
\hline 20 & Зимняк / Rough-Legged Buzzard (Buteo lagopus Pontoppidan, 1763) & $3, P, 2$ \\
\hline 21 & Мамый подорлик / Lesser Spotted Eagle (Aquila pomarina C.L. Brehm, 1831) & 3a, $M, \ni, 1$ \\
\hline- & Большой подорлик / Greater Spotted Eagle (Aquila clanga Pallas, 1811)* & 3a, $M, \ni, 1$ \\
\hline 22 & Степной орёл / Steppe Eagle (Aquila nipalensis Hodgson, 1833) * & 3a, $M, \ni, 1$ \\
\hline 23 & Орёл-могимьник / Imperial Eagle (Aquila heliaca Savigny, 1809)* & Гн, 3, P, 1 \\
\hline- & Беркут / Golden Eagle (Aquila chrysaetos Linnaeus, 1758)* & $3, \ni, 1$ \\
\hline- & Орёл-карлик / Booted Eagle (Hieraaetus pennatus J.F. Gmelin, 1788) & $M, \ni, 1$ \\
\hline
\end{tabular}

Примечание / Notes:

* - вид занесён в Красные Книги Республики Крым и РФ (Сикорский, 2017) / species is listed in the Red Data Books of the Republic of Crimea and the Russian Federation (Sikorsky, 2017);

без нумерации - вид обнаружен в окрестностях заповедника/ without numbering - species found only in the surroundings of the Reserve;

жирный шрифтом отмечены виды, которые были обнаружены автором статьи на территории заповедника за период с 2011 по 2018 гг. / bold type - species discovered by the author on the territory of the Reserve in the period from 2011 to 2018;

характер пребывания в исследуемом районе / status in the studied area: Г - гнездяшийся / breeding, 3 - зимуюший / wintering, М - мигрируюший / migrating, За - заётный / vagrant;

регулярность / frequency: Р - встречается регулярно / осcurs regularly, Н - нерегулярно / irregularly, Э - эпизодически (менее 10 встреч) / sporadically (less than 10 records);

оценка численности (в кол-ве особей дяя негнездяшихся и в кол-ве пар мяя гнездяшихся видов) / estimation of population number (in individuals for non-breeding species and in pairs for nesting species): $1-<10 ; 2-10-50 ; 3-51-100$. 
В настоящей работе приводятся сведения о состоянии фауны хишных птиц заповедника за период с 2010 по 2018 гг. Аля территории собственно заповедника и его окрестностей ( $\Delta$ о 10 км от границ заповедника).

По состоянию на 1 декабря 2018 г. на территории ГБУПЗ “Опукский» и на смежных с ним территориях зарегистрирован 261 виА птиц (77\% крымской фауны птиц),

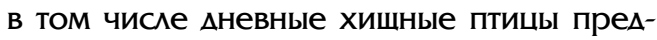
ставлены 28 видами (12\% от обшего количества видов птиц заповедника), которые принамлежат к 12 родам, из которых мишь 10 (36\%) гнездятся относительно регулярно (вкиючая окрестности заповедника).

В табл. 1 приводится современный список видов Аневных хишных птиц, зарегистрированных на территории заповедника «Опукский" и в его окрестностях с 2010 г., вкАючая виды, зарегистрированные $о$ 2010 г. (Костин, Бескаравайный, 2011). Список вкиючает 28 видовых названий птиц (вкАючая 9 видов, которые не были описаны мия этой территории ранее), из них 23 вида встречены на территории заповедника, остаиьные 5 - в окрестностях заповедника (в списке указаны без номера), 12 видов гнездятся, 15 - зимуют (1 редко зимует), 16 - мигрируют. Полученные результаты имеют теоретическую и практическую ценность по оптимизации мероприятий по охране дневных хишных птиц в условиях возрастания антропогенного влияния и глобамьных кииматических изменений (Летопись природы ..., 2017).

Номенкиатура, порядок расположения таксонов, названия виАов и подвиАОв приведены согласно "Списку птиц Российской Федерации" (Коблик и Ар., 2006).

Аия отАельных реАких видов территория заповедника имеет важное значение и во внегнездовой период. Так, территория водно-болотного угодья с прилегаюшими скальными участками, играет важную роль как стабильное место обитания в послегнездовой период курганника (Buteo rufinus), который гнездится на скальных выступах горы Опук и за пределами заповедника в лесопосахках возле населённых пунктов в окружении заповедника. Орлан-белохвост (Haliaeetus albicilla) пери-
Орлан-белохвост (Haliaeetus albicilla). Северная сторона горы Опук, 06.02.2015 г. Фото И. Сикорского.

White-tailed Eagle (Haliaeetus albicilla). North side of Opuk Mountain, 06/02/2015. Photo by I. Sikorsky.
This paper provides information on the state of the fauna of Birds of Prey of the Reserve and its surroundings (up to $10 \mathrm{~km}$ from the boundaries of the reserve) for the period from 2010 to 2018.

As of December $1^{\text {st }}$ of 2018,261 bird species $(77 \%$ of the total Crimean bird fauna) have been registered on the territory of the Reserve and adjacent territories, including 28 species of Birds of Prey (12\% of the total number of bird species in the reserve), which belong to 12 genera. Only 10 species out of 28 (36\%) nest regularly on the studied territory (that includes Reserve and its surroundings).

Table 1 represents a modern list of Birds of Prey species registered on the territory of the Reserve and its surroundings since 2010; it also includes species registered before 2010. (Kostin, Beskaravayny, 2011). The list includes 28 species of raptors (including 9 species that were not reported for the studied territory before), 23 of them are found in the Reserve, the remaining 5 - in the vicinity of the reserve (listed but not numbered in Table 1); 12 species - nesting, 15 - wintering (one - winters very seldom), 16 - migrating. The obtained results are of theoretical and practical value for optimization of Birds of Prey conservation actions under increasing anthropogenic pressure and global climate changes (Chronicle ..., 2017).

Nomenclature, the order of taxa, names of species and subspecies are given according to the "list of birds of the Russian Federation" (Koblik et al., 2006).

For some rare species, the territory of the Reserve is also important in the non-breeding period. For instance, the wetlands with adjacent rocks play an important role as a stable post-breeding habitat for LongLegged Buzzard (Buteo rufinus) that nests on the rocky ledges of Opuk mountain and in forest plantations near settlements outside of the Reserve. We observed a slight increase in the number of White-Tailed Eagle (Haliaeetus albicilla) that periodically winters in low numbers in the southern part

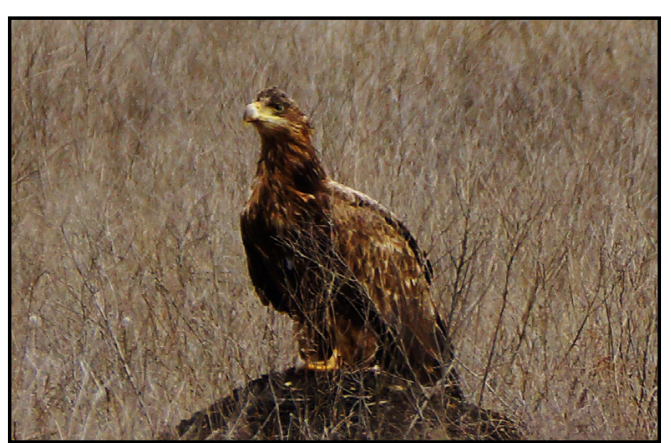


Болотный мунь (Circus aeruginosus). Окрестности с. Марьевка, 05.01.2014 г. Фото И. Сикорского.

Western Marsh Harrier (Circus aeruginosus). The neighborhood of Maryevka, 05/01/2014. Photo by I. Sikorsky.

одически зимует на юге Керченского полуострова в незначительном количестве, причём его численность несколько возросла в последние годы. На территории тектонических разломов горы Опук стабильно гнездятся 2 пары бамобанов (Falco cherrug) (Сикорский, 2014).

Практически все редкие виды птиц наблюдаиись в пределах заповедного объекта. За пределами заповедника наблюдаии гнездование сапсана (Falco peregrinus). Периодически заиетают в заповедник в поисках пиши редкие орёл-могильник (Aquila heliaca) и полевой мунь (Circus cyaneus).

В 2014 г. обнаружено единичное гнезАование степной пустельги (Falco naumanni) в каньоне с юго-запацной стороны плато горы Опук. В гнезде обнаружено 3 птенца (Сикорский, 2016).

В 2018 г. отмечено гнездование чеглока (Falco subbuteo) у восточных границ заповедника, численность которого низкая. Также в 2018 году была зарегистрирована одиночная особь большого подорлика (Aquila clanga) на опушке Марьевского леса возле с. Марьевка.

Состояние охраны птиц в последние годы сушественно не улучшилось. Реацная охрана птиц, точнее территории, сушествует только в пределах заповедника, что предусмотрено его статусом. За его пределами, гАе производится сельскохозяйственная, рекреационная деятельность, охота,

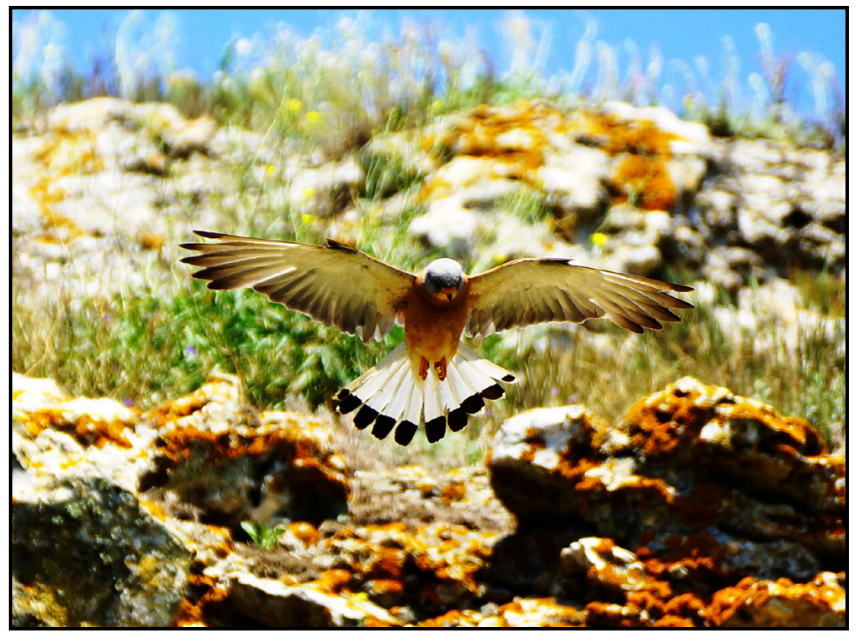

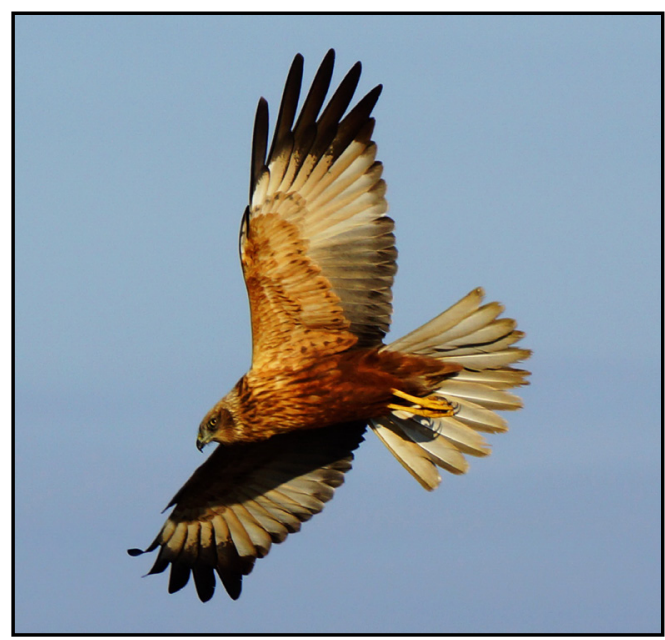

of the Kerch Peninsula. Two pairs of Saker Falcon (Falco cherrug) nest regularly on the territory of tectonic faults of Opuk mountain (Sikorsky, 2014).

Almost all rare species of raptors were observed within the protected area. Only breeding pair of Peregrine Falcon (Falco peregrinus) was observed outside the reserve. Periodically rare Imperial Eagle (Aquila heliaca) and Hen Harrier (Circus cyaneus) visit the Reserve in search for food.

In 2014, a single nesting pair of the Lesser Kestrel (Falco naumanni) was found breeding in the canyon on the South-Western side of the Opuk mountain plateau. Three nestlings were found in the nest (Sikorsky, 2016). In 2018, nesting of the Eurasian Hobby (Falco Subbuteo), which number is low was noted near the eastern borders of the Reserve. Also, in 2018, a single individual of Spotted Eagle (Aquila clanga) was registered at the edge of the Marievskiy forest near the village Maryevka.

The state of bird protection has not improved significantly in recent years. The real protection of birds (in fact - its habitats) exists only within the borders of the Reserve that is provided by its status. Beyond its borders, where agricultural, recreational, and hunting activities are conducted, raptors have been preserved mainly due to the preservation of biotopes. Former military training grounds play an important role for raptors, although a significant part of them was removed for the agricultural needs in recent years.

Степная пустельга (Falco naumanni). Гора Опук, 10.07.2014 г. Фото И. Сикорского.

Lesser Kestrel (Falco naumanni). Opuk Mountain 10/07/2014. Photo by I. Sikorsky. 


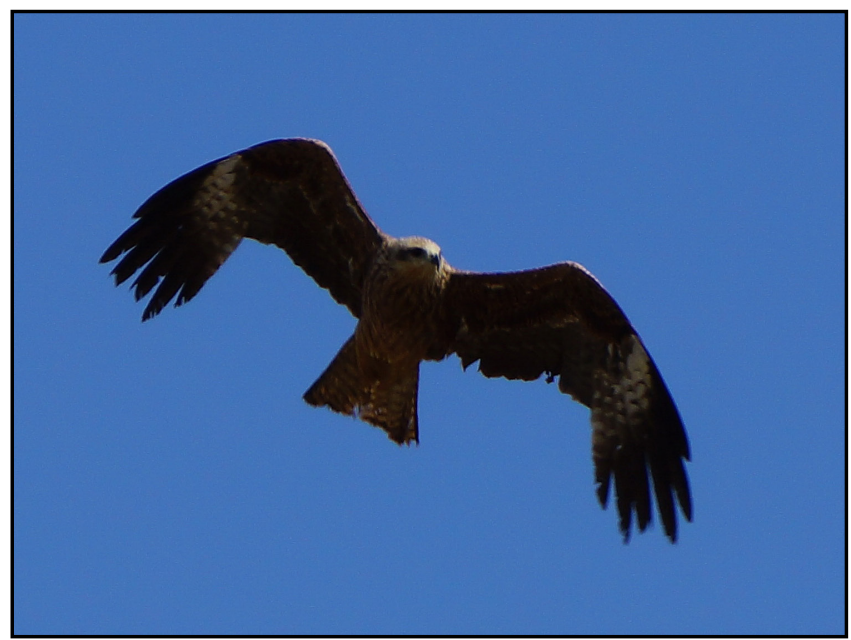

птицы сохранились преимушественно за счет сохранения биотопов. Важную роль мяя птиц имеют территории бывших военных полигонов, хотя значительные плошали их в последние годы оставлены под сельскохозяйственную деятельность.

\section{\итература}

Коблик Е.А., Редькин Я.А., Архипов В.Ю. Список птиц Российской Федерации. М.: Товаришество научных изданий КМК, 2006. 256 с. [Koblik E.A., Red'kin Ya.A., Arkhipov V.Yu. Checklist of the birds of Russian Federation. Moscow: KMK Scientific Press Ltd., 2006: 1-256.] URL: https://www.researchgate.net/profile/Vladimir Arkhipov2/publication/255723014_Checklist_of_the_birds_of_the_Russian_Federation/ links/00b7d520b1f6047198000000/Checklistof-the-birds-of-the-Russian-Federation.pdf $\Delta$ ата обрашения: 20.08.2018.

Костин С.Ю., Бескаравайный М.М. Аннотированный список птиц Опукского природного заповедника. - Научные записки природного заповедника "Мыс Мартьян". 2011. Вып. 2. C. 234-258. [Kostin S.Yu., Beskaravayny M.M. The checklist of the birds for the Opuk Nature Reserve. - Scientific notes of the "Cape Martyan" Nature Reserve. 2011. 2: 234-258.] URL: https://cyberleninka.ru/article/n/annotirovannyy-

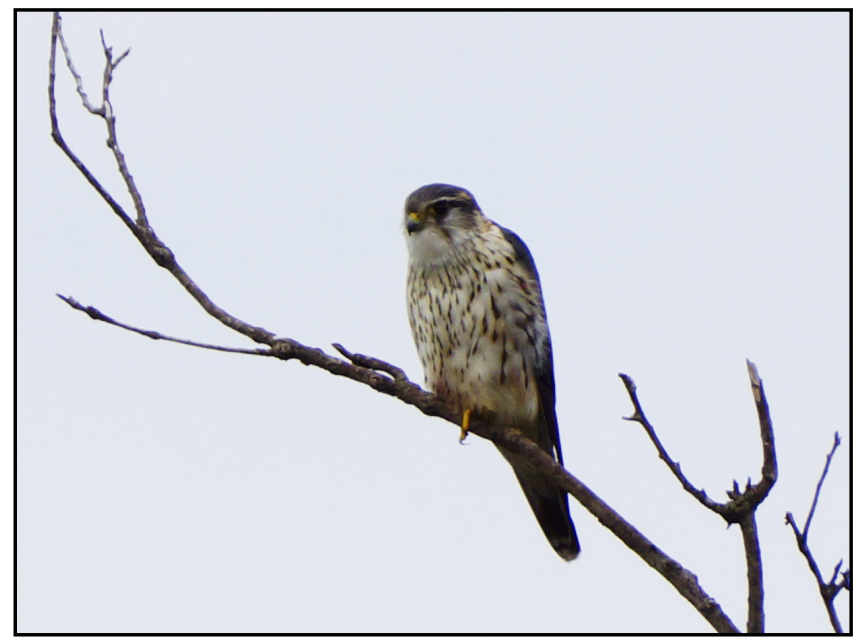

Чёрный коршун (Milvus migrans). Окрестности с. Яковенково, 22.06.2014 г. Фото И. Сикорского.

Black Kite (Milvus migrans). The neighborhood of Yakovenkovo, 22/06/2014. Photo by I. Sikorsky.

spisok-ptits-opukskogo-prirodnogo-zapovednika $\triangle$ ата обрашения: 20.08.2018.

Летопись природы заповедника "Опукский". Том 18. / Сост. И.А. Сикорский. Феодосия, 2017. 148 c. [Chronicle of nature of the Opuksky Nature Reserve. Vol. 18 / Comp. I.A. Sikorsky. Theodosiya, 2017: 1-148.]

Сикорский И.А. Итоги инвентаризации орнитосрауны Опукского природного заповедника и его окрестностей. - Устойчивое развитие особо охраняемых природных территорий: материамы I Всероссийской научно-практической конференции (г. Сочи, 2-4 декабря 2014 г.). Сочи, 2014. C. 204-211. [Sikorsky I.A. The results of the inventory of the avifauna of the Opuksky Nature Reserve and its surroundings. - Sustainable development of Protected Areas: Materials of the I All-Russian Scientific and Practical Conference (Sochi, December 2-4, 2014). Sochi, 2014: 204-211.] URL: https://docplayer. ru/26882842-Ustoychivoe-razvitie-osobo-ohranyaemyh-prirodnyh-territoriy.html $\Delta$ ата обрашения: 20.08.2018.

Сикорский И.А. О статусе степной пустельги (Falco naumanni) в Крыму. - Экологическая безопасность территорий и акваторий: регионаиьные и глобаиьные проблемы. Материаиы региональной научно-практической консеренции (Керчь, 24-28 октября 2016 г.). Керчь, 2016. C. 190-195. [Sikorsky I.A. On the status of the Lesser Kestrel (Falco naumanni) in the Crimea. - Ecological safety of territories and waters: regional and global problems. Materials of the Regional Scientific and Practical Conference (Kerch, October 24-28, 2016). Kerch, 2016: 190-195.]

Сикорский И.А. Состояние популяций краснокнижных виАов орнитосрауны ГБУПЗ "Опукский" и его окрестностей. - Устойчивое развитие особо охраняемых природных территорий. Том 4: Сборник статей IV Всероссийской научно-практической конференции (1-3 ноября 2017 г., Сочи). Сочи, 2017. С. 250-263. [Sikorsky I.A. The state of the populations of the endangered species of the avifauna of the Opuksky Nature Reserve and its surroundings. - Sustainable development of Protected Areas. Volume 4: Collection of articles of the IV All-Russian Scientific and Practical Conference (November 1-3, 2017, Sochi). Sochi, 2017: 250-263.]

$\triangle$ ербник (Falco columbarius). Окраина заповедника "Опукский”, 13.03.2016 г. Фото И. Сикорского.

Merlin (Falco columbarius). The edge of the Opuksky State Nature Reserve, 13/03/2016.

Photo by I. Sikorsky. 